\title{
Effect of seed predation, shade and soil organic matter on the early establishment of eastern white pine and balsam fir seedlings
}

\author{
by Luc C. Duchesne1, ${ }^{1,3}$, D.G. Herr ${ }^{1,2}$, S. Wetzel ${ }^{1}$, I.D. Thompson ${ }^{1}$ and R. Reader ${ }^{2}$
}

\begin{abstract}
Eastern white pine (Pinus strobus L.) does not regenerate well in the absence of fire, or without mechanical exposure of mineral soil, while balsam fir (Abies balsamea L. Mill.) is a common understory species on sites occupied by white pine. We conducted two experiments to explain the difference in regenerative success of these two species. First, the effect of shade and soil organic matter on the emergence of white pine and balsam fir were compared using soil monoliths from a regenerating white pine stand. Balsam fir germination was significantly lower than white pine germination at different shade levels and at different levels of soil organic matter. Second, seed predation was compared between balsam fir and white pine in a non-regenerating white pine stand. Predation of white pine seeds was 10 times greater than balsam fir predation even when seeds of white pine and balsam fir were left as a mixture on the forest floor. We speculate that seed predation is a critical factor in white pine succession and that seed predators favour balsam fir succession by selecting white pine seeds.
\end{abstract}

Key words: seed predation, fire ecology, Pinus strobus, Abies balsamea, Peromyscus maniculatus, succession

Le pin blanc de l'est (Pinus strobus L.) ne se régénère pas adéquatement en l'absence du feu, ou d'exposition mécanique du sol minéral, tandis que le sapin baumier (Abies balsamea L. Mill.) est une espèce commune du couvert de bas étage sur les sites occupés par le pin blanc. Nous avons entrepris deux essais pour expliquer cette différence dans le taux de régénération de ces deux espèces. Premièrement, l'effet de l'ombre et la matière organique du sol sur l'émergence du pin blanc et du sapin baumier ont été comparés en utilisant des blocs monolithes de sol tirés d'un peuplement de pin blanc en régénération. La germination du sapin baumier était significativement inférieure à celle du pin blanc selon différents niveaux d'ombrage et selon différents niveaux de présence de matière organique dans le sol. Deuxièmement, la prédation des semences a été comparée entre le sapin baumier et le pin blanc dans un peuplement de pin blanc qui n'était pas en voie de régénération. La prédation des semences de pin blanc était dix fois supérieure à celle des semences de sapin baumier même lorsque les semences de pin blanc et de sapin baumier avaient été laissées sur le parterre forestier sous forme de mélange. Nous estimons que la prédation des semences est un facteur critique dans la succession du pin blanc et que les prédateurs de semences favorisent la succession du sapin baumier en choisissant les semences de pin blanc.

Mots-clés : prédation des semences, écologie du feu, Pinus strobus, Abies balsamea, Peromyscus maniculatus, succession

\section{Introduction}

Canada's first prime minister, Sir John A. MacDonald, expressed serious concerns about the future of eastern white pine (Pinus strobus L.) forests as early as 1871 (Johnstone 1991). Over the following century, North American forest managers have fought a losing battle with the unpredictable regeneration and/or succession of white pine after harvest (Maissurow 1935, Mayall 1941, Candy 1951). There is no data showing the effect of European settlement on white pine abundance in Canada, but in Minnesota Frelich (1995) reports that white pine forests made up 1.4 million ha in pre-European times whereas they now make up 0.2 million ha.

Contemporary management of white pine is conducted through an intensive two-cut shelterwood system, a technique that yields adequate white pine regeneration in $70 \%$ of ecosystems (Corbett 1994). Ecosystems that fail to regenerate under shelterwood management are often replaced by early successional deciduous ecosystems dominated by trembling aspen (Populus tremuloides Michx.), paper birch (Betula papyrifera Marsh) and balsam fir (Abies balsamea L. Mill.). Pre-European settlement white pine ecosystems were fire-dependant (Heinselman

\footnotetext{
${ }^{1}$ Canadian Forest Service, P.O. Box 490, 1219 Queen Street East, Sault Ste. Marie, Ontario P6A 5M7.

${ }^{2}$ Department of Botany, University of Guelph, Guelph, Ontario N1G 2W1.

${ }^{3}$ Corresponding author.
}

1981) and it is presumed that their maintenance was closely linked to fire (Mc Rae et al. 1994). Under the current fire exclusion policies, the understory of white pine ecosystems tends to be invaded by balsam fir and/or red maple (Acer rubrum L.) whereas white pine regeneration is often lacking (Methven and Murray 1974, Day and Carter 1990, Corbett 1994). In this paper we attempt to explain why balsam fir regeneration is often greater than white pine regeneration in the understory of white pine ecosystems.

The interaction between light conditions, soil organic matter and soil moisture has been blamed for the regeneration failure of conifers in northern ecosystems (reviewed by Herr et al. 1999). White pine is moderately tolerant to shade (reviewed by Wetzel and Burgess 1994) whereas balsam fir is very tolerant to shade (Baker 1949). Therefore, different physiological tolerance to microsite conditions may explain the greater regeneration of balsam fir. Thomas and Wein (1985a, 1985b) showed that balsam fir seeds are more sensitive to moisture stress than white pine in greenhouse conditions while Herr et al. (1999) showed that organic material at the surface of the soil seed beds reduces white pine germination when soil moisture is a critical factor. Recently, Cornett et al. (1998) determined that balsam fir germination and early seedling establishment is more sensitive to soil organic matter than white pine in conifer-deciduous mixed woods of Northern Minnesota. For white pine, the negative impact of soil organic matter on seed germination can 
be negated with shading if there is sufficient soil moisture to support germination (Herr et al. 1999).

Seed predation has been implicated in the failure of artificial and natural seeding programs for many years (see for example Smith and Aldous 1947, Spencer 1954, Abbott 1961, Pank 1974 ) including direct seeding of white pine (Horton and Bedell 1960). Although seeds can be removed by birds, insects and a few other species of small mammals, mice and voles are generally primary seed predators (Abbott and Hart 1960, Pank 1974, Martell 1979, Vander Wall 1994). Evidence for this assertion is twofold. First, several studies have demonstrated that local populations of mice and moles can consume the entire yearly seed crops of eastern white pine (Abbott 1961), white spruce (Radvanyi 1966), Douglas-fir (Pseudotsuga menziesii (Mirb.) Franco) (Gashwiler 1979), western hemlock (Tsuga heterophylla (Raf.) Sarg.) (Gashwiler 1979), and red spruce (Abbott and Hart 1960). Mouse populations of five animals per ha can remove up to 50000 seeds in two weeks (Sullivan 1978). Second, mice populations (Peromyscus spp.) have been reported to fluctuate with tree seed crops (Gashwiler 1979), suggesting a strong relationship between seed abundance and functional and/or numerical responses by mice.

The objective of this investigation was to compare some of the factors that may affect the early regeneration of white pine and balsam fir. First, the effect of different levels of organic material removal and shading on seed germination were compared between white pine and balsam fir in greenhouse conditions using soil monoliths. Second, seed predation was compared between balsam fir and white pine in a white pine stand regenerating with balsam fir but not with white pine.

\section{Materials and Methods Effect of Shade and Organic Matter on Seed Germination}

This experiment was conducted using soil monoliths according to the method of Herr et al. (1995). Soil monoliths were collected from the Frontier Lake experimental site $\left(46^{\circ} 00^{\prime} \mathrm{N}\right.$, $77^{\circ} 33^{\prime} \mathrm{W}$ ) in the Middle Ottawa Section (L.4c) of the Great LakesSt. Lawrence forest region (Rowe 1972). A detailed description of vegetation in this stand was given by Herr et al. (1994). The main overstorey species in the stand include jack pine and eastern white pine; understorey white pine regeneration is present at a density of approximately 40000 seedlings or saplings per ha, which is one of the primary reasons for selecting this site (Duchesne and McAlpine 1993).

Each 18-cm $\times 30-\mathrm{cm}$ monolith (Herr et al. 1995) was first outlined by cutting into the soil with a serrated knife. Then the monolith was excavated to a depth of $25 \mathrm{~cm}$ using a tree planting spade to include the organic horizon, the A horizon, and a portion of the B horizon. Monoliths $(n=75)$ were collected and placed in plastic Rootrainer boxes (Spencer Lemaire Industries Ltd., Edmonton, Alberta) lined with weed barrier nursery cloth (Geosynthetics Systems, Edmonton, Alberta), and transported to a greenhouse.

\section{Removal of Soil Organic Matter}

Before reducing soil organic matter, the depth of the LFH horizons was measured: mean organic horizon thickness, litter (L): $1.3 \mathrm{~cm}$; fermentation(F): $2.2 \mathrm{~cm}$; and, humus $(\mathrm{H}): 3.7 \mathrm{~cm}$. In this investigation $0 \%, 25 \%, 50 \%, 75 \%$, or $100 \%$ of the soil organic matter were mechanically removed using a serrated knife.
Controls ( $0 \%$ reduction) consisted of monoliths in which no organic material was removed; $25 \%$ reduction led to the removal of the $\mathrm{L}$ horizon and some of the $\mathrm{F}$ horizon; $50 \%$ reduction led to the removal of all the $\mathrm{L}$ and $\mathrm{F}$ horizons and some of the $\mathrm{H}$ horizon; $75 \%$ removal led to the elimination of all of the $\mathrm{L}$ and $\mathrm{F}$ horizons and more or less half the $\mathrm{H}$ horizon; and $100 \%$ removal led to the elimination of all the $\mathrm{L}, \mathrm{F}$, and $\mathrm{H}$ horizons (Herr 1995).

\section{Effect of Shading on Seedling Emergence}

Germinating seeds of both species were subjected to three shading levels to ascertain whether they exhibit different tolerance to shading. Shade at the ground level of the monolith collection site was measured $(\mathrm{N}=50)$ at solar noon on June 3, 1993, a clear and sunny day, using a Li-Cor LI-190SZ Quantum sensor (Li-Cor, Lincoln, Nebraska, USA) and showed 26.5\% of the photosynthetically active radiation (PAR) found in an a nearby clearcut without interference from vegetation. This data was used to determine three shading levels for this experiment: 1) uncut: ground level shade from the monolith collection site ( $26.5 \%$ of maximum PAR) to mimic natural conditions of mature white pine stands; 2 ) shelterwood: decreased shade (39\% of maximum PAR to mimic shading conditions in shelterwood cuts); and, 3) clearcut: increased shade (14.5\% of maximum PAR) to mimic excessive competition in clear-cuts or under dense canopies. Five monoliths from each of the organic horizon reduction levels $(0 \%, 25 \%, 50 \%, 75 \%$, or $100 \%)$ were subjected to one of three shading regimes. In the greenhouse, the shade level was controlled by suspending a wooden lattice $25 \mathrm{~cm}$ above the monoliths. The number of slats in the lattice was adjusted until the desired PAR level was obtained. Each monolith received $100 \%$ of the local 30 -year average daily June rainfall (145 $\mathrm{ml}$ deionized water per day). This watering regime was selected as the best scenario for seed germination, although we recognize that in situ germination is partly limited by rainfall variations.

\section{Seedling Emergence}

White pine and balsam fir seeds were cold-stratified using the method of Creasey and Myland (1992). Seeds used in this investigation were obtained from the National Forest Genetics Resource Centre Seed Bank (NFGRCSB) at the Petawawa National Forestry Institute (PNFI) (White pine: seed lot No $8930585,97 \%$ viability in vitro; Balsam fir: seed lot No $9130077.0,61 \%$ viability). Seed viability was tested one month before the onset of this experiment and was used to standardize viable seed number among the two species as the number of seeds required to achieve 50 viable seeds per treatment was used for seeding the monoliths: 52 white pine seeds and 89 balsam fir seeds. Seeds were broadcast on the monolith surface. The monoliths were kept in a greenhouse with an ambient air temperature at monolith surface (without shade) of $23.8 \pm 4.3^{\circ} \mathrm{C}$. It was not possible to control relative humidity inside the greenhouse.

Every second day, the number of seed coats that had lifted off the monolith substrate (i.e., seedling emergence) of each monolith was counted and removed. At the end of seven weeks, after which no new seedling emerged, percent seedling emergence was calculated for each species and treatment combination expressed as a percentage of the total number of viable seeds for each species. 
Table 1. Characteristics of dominant vegetation at the Echo Bay site. Algoma district, Ontario

\begin{tabular}{lccc}
\hline Species & Stems/ha & $\begin{array}{c}\text { Mean age } \\
\text { (years) }\end{array}$ & $\begin{array}{c}\text { Mean DBH } \\
(\mathbf{c m})\end{array}$ \\
\hline Pinus strobus L. & 20 & 115 & 42.3 \\
Picea glauca (Moench) Voss & 23 & 112 & 36.1 \\
Populus tremuloides Michx. & 120 & 55 & 31.2 \\
Abies balsamea (L.) Mill. & 520 & 21 & 11.3 \\
\hline
\end{tabular}

Seed Predation in a Non-regenerating White Pine Stand

To compare seed predation of white pine and balsam fir, seeds of both species were placed in a white pine ecosystem (Table 1) with abundant balsam fir regeneration (4000 seedlings and saplings/ha) and poor white pine regeneration $(<100$ seedling and saplings/ha). The experimental site is located near Echo Bay, Ontario, Canada, $\left(46^{\circ} 25^{\prime} \mathrm{N}, 84^{\circ} 02^{\prime} \mathrm{W}\right)$, approximately 28 kilometres southeast of Sault Ste. Marie, within the Algoma Section (L.10) of the Great Lakes-St. Lawrence Forest Region (Rowe 1972). This site was selected over the Frontier Lake site for its lack of white pine regeneration. White pine was extensively harvested from the site in the 1920s (J. Krohn, personal communication). There is no evidence of fire scars for the past 70 years. Understorey vegetation consisted mostly of Aralia nudicaulis L., Aster macrophyllus L., Pteridium aquilinum (L. ) Kuhn. and Corylus cornuta Marsh. The soil is a Gleyed Gray Luvisol over a thick (>10 m) clay-loam deposit (Agriculture Canada 1983).

Unstratified seeds of white pine and balsam fir (same seed lots as above) were placed in polyvinyl chlorine (PVC) rings and left in the field for two weeks. The rings consisted of $8-\mathrm{cm}$ diameter PVC pipes cut in 3-cm sections. A piece of nylon mesh $(1 \mathrm{~mm})$ taped to the bottom of the rings prevented the seeds from mixing with forest floor material while allowing rainwater to drain. Three treatments were used for this experiment: 1) rings with one hundred seeds of balsam fir; 2) rings with one hundred seeds of white pine; and, 3) rings with one hundred seeds of white pine and one hundred seeds of balsam fir. The three rings of each treatment were placed $1 \mathrm{~m}$ apart in a triangular pattern. Twenty such triangles were randomly placed through the stand for a total of sixty rings. After two weeks, the content of the rings was transferred to plastic bags and the number of whole seeds subsequently counted in the laboratory. This experiment was repeated three times from October 1, 1998 to October 14, 1998, November 1 to November 14, 1998, December 16, 1998 to May 1, 1999 by using the identical locations for the rings.

\section{Statistical Analyses}

Effects of treatments on seedling emergence were performed using analysis of variance (ANOVA). Total percent emergence data was arcsine-transformed and tested for homoscedasticity prior to ANOVA using SAS (SAS Institute Inc. 1990). When ANOVA results indicated a significant treatment effect, Tukey's HSD test was performed on each reduced data set to determine which levels of the treatments differed (Sokal and Rohlf 1981).

\section{Results \\ Effect of Shade and Organic Matter on Seed Germination}

Mean white pine emergence (Fig. 1) ranged widely from a minimum of $4 \%$ for the $0 \%$ organic horizon reduction under shelterwood shade level to a maximum of $97 \%$ for the $100 \%$ organic horizon reduction under the clearcut shade level. Balsam fir seedling emergence (Fig. 1) ranged from a minimum of $6 \%$ for the $0 \%$ organic horizon reduction under the shelterwood shade level to a maximum of $86 \%$ for the $100 \%$ organic horizon reduction under the shelterwood shade level.

The effect of organic horizon reduction on seedling emergence was significant at $\mathrm{P}<0.001$ (Fig. 1). Mean seedling emergence of both species increased with the removal of organic matter, regardless of the shade level. However, the positive effect of organic matter removal on seedling emergence was negated by increasing the amount of light to the monoliths. This effect was more pronounced for balsam fir than for white pine. Shading has a significant effect on seed germination $(\mathrm{P}<0.001)$ as seedling germination increased with the amount of shade delivered to the monoliths.

\section{Seed Predation in a Non-regenerating White Pine Stand}

White pine seed predation $(70.4 \%)$ was significantly different from balsam fir seed predation $(5.0 \%)$ (Table $2, \mathrm{P}=0.008$ ). The rate of predation of each species was not significantly affected by mixing species together. In most rings we found empty shells of white pine or balsam fir seeds suggesting that some of the seeds were consumed within the proximity of the rings.

\section{Discussion}

Although seed predation has been implicated in the failure of artificial and seed programs of white pine, this investigation provides the first evidence that seed predators actively select white pine seeds over balsam fir seeds and that they reject balsam fir seeds. This conclusion is based on our observation that the predation rates of balsam fir seeds was not affected when both species were mixed together. Our results are similar to those of Abbott and Hart (1960) who demonstrated that deer mice (Peromyscus maniculatus Wagner) and red backed voles (Clethrionomys gapperi Vigors) prefer red spruce (Picea rubens Sarg.) seeds over balsam fir seeds. Moreover, mice and voles consumed and/or cached a quantity of red spruce seeds greater than the natural seed crop, thus seed predation was speculated to be a limiting factor determining the low ratio of red spruce to balsam fir regeneration in the Northeast US (Abbott and Hart 1960).

Differential seed predation may have long lasting impact on ecosystem succession. For example, Cornett et al. (1998) demonstrated that regeneration success of white pine seeds after two years was increased threefold by controlling seed predation using caging experiments whereas the regeneration of balsam fir was marginally improved by controlling seed predation. As well, Abbott (1961) reported that deer mice and red backed voles can destroy white pine seeds in excess of the natural seed crops. Although we did not investigate the abundance of mice and voles in our research site, population densities of seven animals per ha found in central Ontario (I.D. Thompson, unpublished results) are comparable to the those found by Abbott (1961).

In this investigation we observed that germinating seedlings of white pine and balsam fir exhibit comparable tolerance to shade and soil organic matter. Hence, our observations do not support the hypothesis that balsam fir germinating seeds and young seedlings are better adapted to understorey and clearcut conditions than white pine. However, our findings suggest that shade has a favourable effect on the early establishment of both white pine and balsam fir seedlings. Indeed, in this investigation, 
Balsam fir--clear-cut

Balsam fir--undisturbed

Balsam fir--shelterwood

White pine--clear-cut

White pine--undisturbed

White pine--shelterwood

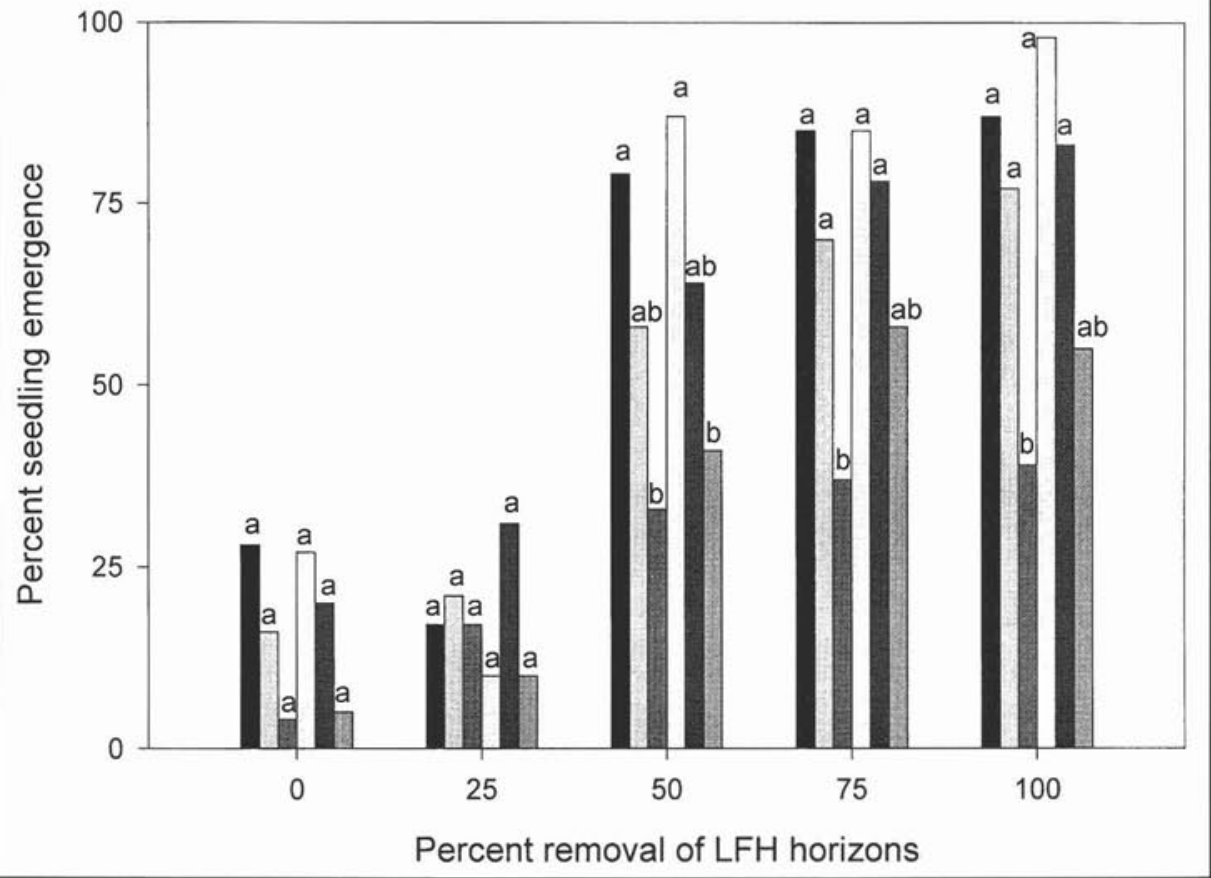

Fig. 1. Effect of three shade conditions and organic horizon thickness of white pine and balsam fir on seedling emergence on soil monoliths in greenhouse conditions. Values followed by a different letter are significantly different at $\mathrm{P}<0.05$. Clear-cut: $14.5 \%$ PAR; Undisturbed: $26.5 \%$ PAR Shelterwood: $39.0 \%$ PAR.
Table 2. Average predation of white pine and balsam fir seeds in seed trays in a non-regenerating white pine stand. Trays with single species contained 100 seeds of either balsam fir or white pine whereas trays with mixed species were contained 100 seeds of both species. $(\mathrm{N}=20$ ). Values followed by a different letter are significantly different at $\mathrm{P}<0.02$

\begin{tabular}{lcc}
\hline & White pine & Balsam Fir \\
\hline Single species & $70.44 \mathrm{a}$ & $5.00 \mathrm{~b}$ \\
Mixed species & $60.44 \mathrm{a}$ & $17.22 \mathrm{~b}$ \\
\hline
\end{tabular}

increasing the amount of shade available to the seedlings improved seedling establishment whereas decreasing the amount of shade reduced seedling establishment. In other studies we demonstrated that shading, when applied within tolerable physiological ranges, can improve early seedling establishment through improved soil moisture retention (Herr and Duchesne 1995a, 1995b; Duchesne et al. 1999; Herr et al. 1999).

Cornett et al. 1998 reported that seed predation had a greater impact on long-term regeneration success than control of understory competition or litter removal of both white pine and balsam fir. In contrast, the silviculture of early white pine regeneration is guided by three principles: 1) seedbeds should be prepared to mineral soil, either through wildfire, prescribed fire or ground scarification, to help with the natural germination of white pine seeds (McRae et al. 1994); 2) the regener- ating cohort should be protected from excessive competition by opening the canopy through shelterwood or gap cuts; and 3 ) the residual canopy should allow protection against white pine weevil (Pissodes strobi Peck.) attacks. However, little or no attention is paid to the animals that consume seeds, or germinating seedlings. Our results, along with those of Cornett (1998) suggest that silvicultural guidelines for white pine should emphasize seed predation as a factor affecting succession.

Numerous studies show that fire has a positive role on ecosystem productivity by releasing nutrients, controlling competing vegetation and preparing suitable germination seedbeds. However, in view of our observations the role of fire in the control of seed predation remains to be examined. In general, mice and voles populations are temporarily eliminated or reduced by fire through combustion, suffocation or shelter removal (Cook 1959, Ahlgren and Ahlgren 1960) but jack pine communities are quickly recolonized after fire (Ahlgren 1966). We speculate that fire plays a dual role in white pine regeneration by reducing, albeit temporarily, seed predation and creating suitable seedbed conditions for the germination and establishment of surviving seeds.

The management implications of our findings are twofold: on the one hand the reduction of soil organic matter from the seedbed increases seed gemination and early seedling establishment. On the other hand, control of seed predation may be needed to promote and increase white pine regeneration in those ecosystems that are difficult to regenerate. 


\section{References}

Abbott, H.G. 1961. White pine seed consumption by small mammals. Journal of Forestry 59:197-201.

Abbott, H.G. and A.C. Hart. 1960. Mice and voles prefer spruce seeds. Northeastern Forest Experiment Station USDA Forest Service Paper No 153. 12p.

Agriculture Canada. 1983. Soil survey report 50. Bruce Mines 41 J/5. Cartography Section, Land Resource Research Institute, Research Branch Agriculture Canada. Ottawa.

Ahlgren, C.E. 1966. Small mammals and reforestation following prescribed burning. Journal of Forestry 64: 614-618.

Ahlgren, I.F. and C.E. Ahlgren. 1960. Ecological effects of forest fires. The Botanical Review 26: 483-533.

Baker, F.S. 1949. A revised tolerance table. Journal of Forestry 47: 179-181.

Candy, R.H. 1951. Reproduction on cut-over and burned-over land in Canada. Department of Resources and Development, Government of Canada. Ottawa. Forest Research Division Silvicultural Note No 92.

Cook, S.F. 1959. The effect of fire on a population of small rodents. Ecology 40:1 02-108.

Corbett, C.M. 1994. White pine management and conservation in Algonquin Park. For. Chron. 70: 435-437.

Cornett, M.W., K.J. Puetmann and P.B. Reich. 1998. Canopy type, forest floor, predation, and competition influence conifer seedling emergence and early survival in two Minnesota conifer-deciduous forests. Can. J. For. Res. 28: 196-205.

Creasey, K.R. and T.R. Myland. 1992. Guidelines for seed Pretreatment. Forest Resources Group, Nursery and Seed Section. OMNR, Southern Ontario Unit, Angus, Ontario.

Day, R.J. and J.V. Carter. 1990. Stand structure and successional development of the white pine and red pine communities in the Temagami forest. Ontario Ministry of Natural resources. 203 p.

Duchesne, L.C. and R.S. McAlpine. 1993. Effect of prescribed burning and clear-cutting on carabid beetle biodiversity in a jack pine forest. Petawawa National Forestry Institute Technical Report No. 16. Chalk River, Ontario. 5p.

Duchesne, L.C., C. Mueller-Rowat, L.M. Clark and F. Pinto. 1999. Effect of organic matter removal, ashes and shading on Tsuga canadensis seedling emergence from soil monoliths under greenhouse conditions. Canadian Field Naturalist 113: 264-268.

Frelich, L.E. 1995. Old forest in the Lake States today and before European settlement. Natural Areas Journal 15: 157-167.

Gashwiler, J.S. 1979. Deer mouse reproduction and its relationship to the tree seed crop. The American Midland Naturalist 102: 95-104. Heinselman, M.L. 1981. Fire intensity and frequency as factors in the distribution and structure of the northern ecosystems. In H.A. Mooney, J.M. Bonnicksen, N.L. Christensen, J.E. Lotan and W.A. Weiners (eds.). Fire regimes and ecosystem properties. U.S.For. Serv. Gen. Tech. Rep. WO-26. 7-57.

Herr, D.G. 1995. Effects of simulated prescribed burning, water regime and shading on white pine and balsam fir seedling emergence. MSc dissertation. Department of Botany, University of Guelph, Ont. Canada. 95 p.

Herr, D.G., J.L. Cooper, L.C. Duchesne and R.J. Reader. 1995. Modeling seedling emergence using soil monoliths. Petawawa National Forestry Institute technical report 17. Chalk River, Ontario. $7 \mathrm{p}$.

Herr, D.G. and L.C. Duchesne. 1995a. Effect of organic horizon thickness, shading, ashes and watering regime on red pine seed emergence. Can. J. For. Res. 26: 422-427.
Herr, D.G. and L.C. Duchesne. 1995b. Effect of water regime, cover, organic horizon thickness, and ashes on jack pine seedling emergence. Water, Air and Soil Pollution 82: 147-154.

Herr, D.G., L.C. Duchesne and R. J. Reader. 1999. Effects of soil organic matter, moisture, shading and ash on white pine (Pinus strobus L.) seedling emergence. New Forests 18: 219-230.

Herr, D.G., L.C. Duchesne, R. Tellier, R.S. McAlpine and R.L. Peterson. 1994. Effect of prescribed burning on the ectomycorrhizal infectivity of a forest soil. International Journal of Wildland Fire 4: 95-102.

Horton, K.W. and G.H.D. Bedell. 1960. White pine and red pine: ecology, silviculture and management. Ministry of Northern Affairs and National Resources, Ottawa. 185 p.

Johnstone, K. 1991. Timber and trauma: 75 years with the federal forestry service 1899-1974. Forestry Canada. Ottawa Ontario. $194 \mathrm{p}$.

McRae, D.J., T.J. Lynham and R.J. Frech. 1994. Understory prescribed burning in red and white pine. For. Chron. 70: 395-401. Maissurow, D.K. 1935. Fire as a necessary factor in the perpetuation of white pine. Journal of Forestry 33: 373-378.

Martell, A.M. 1979. Selection of conifer seeds by deer mice and redbacked voles. Can. J. For. Res. 9: 201-204.

Mayall, K.M. 1941. White pine succession as influenced by fire. National Research Council of Canada B associate committee on forestry. NRC no 989.29 p.

Methven, I.R. and W.G. Murray. 1974. Using fire to eliminate understory balsam fir in pine management. For. Chron. 50: 77-79.

Pank, L.F. 1974. A bibliography of seed-eating mammals and birds that affect forest regeneration. U.S. Dep. Inter., Fish Wild. Serv. Sci. Rep. Wild Note 174.

Radvanyi, A. 1966. Destruction of radio-tagged seeds of white spruce by small mammals during summer months. Forest Science 12: 307-315.

Rowe, J.S. 1972. Forest Regions of Canada. Can. For. Serv., Publication Number 1300.

SAS Institute Inc. 1990. SAS User's guide: Statistics, Version 6. SAS Institute Inc., Cary, N.C.

Smith, C.F. and S.E. Aldous. 1947. The influence of mammals and birds in retarding artificial and natural reseeding of coniferous forests in the United States. Journal of Forestry 45: 361-369.

Sokal, R.R. and F.J. Rohlf. 1981. Biometry, second edition. W.H. Freeman and Co. San Francisco. 859 p.

Spencer, D.A. 1954. Rodents and direct seeding. Journal of Forestry 52: 824-826.

Sullivan, T.P. 1978. Biological control of conifer seed damage by the deer mouse Peromyscus maniculatus). Proceedings Vertebrate Pest Control Conference 8: 237-250.

Thomas, P.A. and R.W. Wein. 1985a. The influence of shelter and the hypothetical effect of fire severity on the postfire establishment of conifers from seed. Can. Jour. For Res. 15: 148-155.

Thomas, P.A. and R.W. Wein. 1985b. Water availability and the comparative emergence of four conifer species. Canadian Journal of Botany 63: 1740-1746.

Vander Wall, S.B. 1994. Removal of wind-dispersed pine seeds by ground-foraging vertebrates. Oikos 69: 125-132.

Wetzel, S., and D. Burgess. 1994. Current understanding of white and red pine physiology. For. Chron. 70: 420-426. 